\title{
Employment Equality Under the Pregnancy Discrimination Act of 1978
}

Pregnancy discrimination exhibits a coherent social logic. The exclusion of women from employment on the basis of pregnancy perpetuates the sexual division of productive and reproductive labor, thereby confirming women's second class status in the work force. The Pregnancy Discrimination Act of $1978^{1}$ amends Title VII of the Civil Rights Act of $1964^{2}$ by clarifying that the Act's proscription of sex-based employment discrimination includes discrimination on the basis of pregnancy. ${ }^{3}$ The PDA has been construed to require that pregnant employees be treated comparably with others on the basis of ability or inability to work. ${ }^{4}$ This Note challenges the sufficiency of a standard of comparable treatment on statutory and broader, equitable grounds.

When construed as integral to Title VII, the PDA authorizes both a disparate treatment and a disparate impact cause of action. It thus entitles plaintiffs to challenge overtly exclusionary and facially neutral practices ${ }^{b}$ that circumscribe women's employment opportunities on the basis of pregnancy. ${ }^{6}$ Under Title VII as amended, women are entitled to demand, not

1. Pub. L. No. 95-555, § 1, 92 Stat. 2076, 2076 (codified at 42 U.S.C. $\S 2000$ e(k) (1982)) [hereinafter cited as "the PDA" or "the amendment"].

2. 42 U.S.C. $\$ \S 2000$ e to $2000 \mathrm{e}-17$ (1982) [hereinafter cited as "Title VII" or "the Act"].

3. The PDA amends Title VII's definitional provisions, and reads in relevant part:

The terms "because of sex" or "on the basis of sex" include, but are not limited to, because of or on the basis of pregnancy, childbirth, or related medical conditions; and women affected by pregnancy, childbirth, or related medical conditions shall be treated the same for all employment-related purposes, including receipt of benefits under fringe benefit programs, as other persons not so affected but similar in their ability or inability to work, and nothing in section $2000 \mathrm{e}-2(\mathrm{~h})$ of this title shall be interpreted to permit otherwise.

42 U.S.C. $\S 2000 \mathrm{e}(\mathrm{k})(1982)$.

4. See infra pp. 931-33.

5. Facially neutral practices susceptible to disparate impact challenge include leave policies and job definitions, discussed infra Part II.

6. The coverage of the PDA is limited to "pregnancy, childbirth, or related medical conditions." 42 U.S.C. $\S 2000 \mathrm{e}(\mathrm{k})$ (1982). Pregnancy and childbirth are moments in the human reproductive process specific to women, and must be distinguished from childrearing, the social process of parenting, commonly performed by women, but not biologically specific to them. Conflicts between parenting and employment, no less than conflicts between pregnancy and employment, have a disparate impact on women in the workplace. Both institutionally enforce women's relegation to the domestic sphere. See Frug, Securing Job Equality for Women: Labor Market Hostility to Working Mothers, 59 B.U.L. REv. 55 (1979). However, as a legal matter, the problems they pose remain distinct. Conflicts between parenting and employment require solution in gender neutral terms, see, e.g., Comment, Parental Leaves of Absence for Men, 31 BufFalo L. REv. 273 (1982), and, as such, remain outside the scope of the present discussion. 
only comparable treatment, but that measure of institutional accommodation necessary to bear children without forfeit of employment opportunities. So construed, the PDA will secure for women a workplace organized with reference to female, as well as male, reproductive norms. ${ }^{7}$

The debate over the proper construction of the PDA is significant for sex discrimination doctrine generally. Where doctrine has understood equality as a relation between the similarly situated, ${ }^{8}$ a theory of equality recognizing reproductive difference is necessary to implement the PDA's proscription of pregnancy-based employment discrimination. Unlike discrimination premised on stereotypical distinctions between the sexes, pregnancy discrimination involves the social valuation of a real sexual difference. This process of valuation is both institutional and ideological; attitudes about women's reproductive role produce, and are produced by, institutional arrangements that define a biological capacity as a social disability. Doctrine has inquired whether pregnancy is like or unlike other sex-common conditions, hence deserving of comparable treatment. It has framed the question so as to miss the fundamental issue for equality analysis: How, as a sex-specific capacity, is women's reproductive role systematically devalued? The PDA offers doctrine an opportunity to move beyond formal concepts of equality between the sexes, and identify the real institutional barriers to its attainment.

\section{INTERPRETING THE PDA}

The decision of the United States Supreme Court in General Electric Co. v. Gilbert ${ }^{9}$ provided the immediate impetus for the passage of the PDA. In Gilbert, the Court held that, under Title VII, the exclusion of pregnancy coverage from an otherwise comprehensive disability benefits program did not constitute discrimination on the basis of sex. The Court reasoned that the pregnancy classification was not sex-based, as it divided

7. The workplace may be organized to accommodate or to conflict with biological necessities (eating, sleeping, childbirth) and dysfunctions (illness, injury). The organization of the workplace does not in any sense reflect the realities of biological process, but, rather, social judgments as to the importance of accommodating them. Eighty-five percent of working women are likely to become pregnant at least once during their working lives. S. Kamerman, A. KaHN \& P. Kingston, Maternity PoliCIES AND WORKING WOMEN 25 (1983) [hereinafter cited as S. KaMERMAN]. A workplace that does not provide for pregnancy in the normal course of employment is organized around male reproductive norms, reflecting a social judgment that women's necessary role in the human reproductive process is incompatible with employment, as society chooses to define it.

8. For the classic formulation of this thesis, see Tussman \& tenBrouk, The Equal Protection of the Laws, 37 CaLIF. L. REv. 341 (1949). For a critique of the model as indeterminately formal, see Westen, The Empty Idea of Equality, 95 HARv. L. REv. 537 (1982). For a feminist critique of this concept of equality, see C. MacKinnon, Sexual Harassment of Working Women 101-141 (1979). The broader equitable implications of the debate over the PDA's construction are discussed infra Part V.

9. 429 U.S. 125 (1976). 
the universe of beneficiaries into "'pregnant women and nonpregnant persons." "10 It further asserted that because pregnancy was "an additional risk, unique to women," there could be no sex discrimination in excluding its coverage. ${ }^{11}$

Congress moved swiftly to repudiate the Court's construction of Title VII. It passed the Pregnancy Discrimination Act of $1978,{ }^{12}$ which effectively reversed Gilbert by amending the definitional provisions of Title VII to include pregnancy within the meaning of "sex."13 A debate is now taking shape over the proper construction of the amendment, ${ }^{14}$ as the range of challenged practices widens beyond the disability benefits context.

\section{A. Current Interpretation of the PDA}

As currently construed, the PDA requires that employers treat the pregnant employee the same as others on the basis of ability or inability to work. ${ }^{15}$ This "parity of treatment" standard is of immediate practical

10. 429 U.S. at 135. In so holding, the Court adopted the reasoning of Geduldig v. Aiello, 417 U.S. 484 (1974) (equal protection challenge to state disability benefits program). Geduldig still controls as a matter of constitutional law. But of. Hanson v. Hoffmann, 628 F.2d 42, 47-48 (D.C. Cir. 1980) (developments in Title VII doctrine may modify constitutional analysis under Geduldig). For a critique and proposed revision of equal protection analysis as it bears on the issue of reproductive difference, see Law, Rethinking Sex and the Constitution, 132 U. PA. L. REv. 955 (1984).

11. 429 U.S. at 139. In his opinion for the Court, Justice Rehnquist thus advanced an assimilationist theory of equality: Women can seek equality with men only to the extent they are like men. By its terms no equality claim could be made out with respect to pregnancy, even where, as in Gilbert, a program provided benefits for all other disabilities-including those specific to the male reproductive system. Gilbert's reasoning was unequivocally rejected by Congress in passing the PDA. See infra note 13 and accompanying text. The central question posed by the Gilbert decision remains, however, unresolved: To what extent may women raise equality claims based on the sexual difference posed by pregnancy? This question organizes the debate over the proper construction of the PDA which this Note joins.

12. 42 U.S.C. $\S 2000 \mathrm{e}(\mathrm{k})(1982)$. The relevant text of the PDA is quoted supra note 3.

13. Once pregnancy is legally defined as a classification on the basis of sex, a comprehensive disability benefits program that excludes coverage only for pregnancy must automatically violate Title VII. For congressional criticism of the Gilbert opinion, see H.R. REP. No. 948, 95th Cong., 2d Sess. 2-4 (1978), reprinted in 1978 U.S. Code CoNG. \& AD. News 4749-65; S. ReP. No. 331, 95th Cong., 1st Sess. 2-3 (1977).

14. Because the amendment's force is prospective, the majority of pregnancy discrimination claims litigated since the PDA's passage have been decided under pre-amendment law. Only recently has a body of law construing the PDA begun to accumulate. See infra notes 15, 21, 55, 71, 72, 80 .

15. Parity defenses have been accepted in numerous cases litigated under the PDA. See, e.g., California Fed. Sav. \& Loan Ass'n v. Guerra, 34 Fair Empl. Prac. Cas. (BNA) 562 (G.D. Cal. 1984); Brown-Weathersby v. Seaway Nat'l Bank, No. 82-C-2351, slip op. (N.D. Ill. May 4, 1983); Marafino v. St. Louis County Circuit Court, 537 F. Supp. 206 (E.D. Mo. 1982), affd, 707 F.2d 1005 (8th Cir. 1983); Barone v. Hackett, 28 Fair Empl. Prac. Cas. (BNA) 1765 (D.R.I. 1982); Conners v. University of Tenn. Press, 558 F. Supp. 38 (E.D. Tenn. 1982).

The parity interpretation has received its most sustained explication and defense to date in Williams, The Equality Crisis: Some Reflections on Culture, Courts, and Feminism, 7 WoMEs's RTs. L. REP. 175, 190-200 (1982). Even commentators who criticize the parity standard on equitable grounds have nonetheless presumed it to control as a matter of law under Title VII, as amended. See, e.g., 1 A. Larson \& L. LaRson, EMPloyment Discrimination $\S 38.22$ at 8-34 to 8-35 (1984); 
power. It bars pregnancy-specific benefit exclusions of the type at issue in Gilbert, as well as leave requirements, hiring and firing practices, and any other policy that singles out pregnancy for exclusionary treatment. ${ }^{16}$ The pregnant employee cannot be compelled to take leave when others are not, nor denied leave to which others are entitled.

Despite its capacity to proscribe many traditional forms of pregnancy discrimination, the parity standard in fact represents a narrow construction of the PDA. The constraints it imposes on the amendment's coverage flow from its strictly formal definition of equality. As currently construed, the PDA ratifies all practices that treat pregnancy comparably with other disabilities, even though such facially neutral practices may have an exclusionary impact on pregnant employees. Thus, courts have held there to be no cognizable sex discrimination in a facially neutral leave policy inadequate for childbearing, even though such a policy ensures the termination of the pregnant employee as surely as would a pregnancy-specific dismissal rule. ${ }^{17}$ Such gaps in coverage affect those most in need of the PDA's

Furnish, Prenatal Exposure to Fetally Toxic Work Environments: The Dilemma of the 1978 Pregnancy Amendment to Title VII of the Civil Rights Act of 1964, 66 IowA L. REv. 63, 83-84, 103 (1980); Krieger \& Cooney, The Miller-Wohl Controversy: Equal Treatment, Positive Action and the Meaning of Women's Equality, 13 Golden GATE U.L. Rev. 513, 518-19 (1983); Scales, Towards a Feminist Jurisprudence, 56 IND. L.J. 375, 403-04 (1981). But cf. Comment, Sexual Equality Under the Pregnancy Discrimination Act, 83 Colvm. L. REv. 690 (1983) (pluralist model of equality recognizing differences between sexes appropriate to construing PDA); Rigler, Newport News Shipbuilding \& Dry Dock Co. v. EEOC and Sex Discrimination Under Title VII: Some Questions Answered, Others Remain, 88 Dick. L. REv. 357, 364-66 (1984) (status of disparate impact claims under PDA unresolved); Note, The 1978 Pregnancy Discrimination Act: A Problem of Interpretation, 58 WASH. U.L.Q. 607 (1980) (congressional endorsement of parity principles and conflicting EEOC disparate impact guideline necessitates judicial resolution of PDA's mandate).

16. The EEOC has published a list of 37 questions and answers detailing the application of parity principles to a range of employment practices affected by the amendment's passage. See 29 C.F.R. Pt. 1604 app. (1984). Cases litigated under pre-PDA law demonstrate the prevalence and variety of such practices. They include: conditioning job eligibility upon pregnancy or fertility; reversal of decision to hire upon notice of pregnancy; immediate termination upon notice of pregnancy; conditioning of employment upon immediate notification of pregnancy or upon continued medical verification of ability to perform; conditioning eligibility for maternity leave upon years of service; "stop work" policies requiring unpaid maternity leave to begin at the onset of pregnancy or several months thereafter; denial of fringe benefits during maternity leave (inclusive of disability benefits, sick leave, and company paid health insurance premiums); conditioning eligibility for pregnancy benefits upon marital status; "start work" policies forbidding return to work until weeks or months after delivery (or the onset of a normal menstrual cycle, see Harper v. Thiokol Chem. Corp., 619 F.2d 489 (5th Cir. 1980)); loss of seniority upon return from leave; refusal to guarantee reinstatement; and conditional reinstatement which may involve extensive delays, placement in another job, or reduction in hours.

It is this tradition of aggravated hostility to pregnancy in the workplace that gives the parity standard its transformative power. The simple imperative of comparable treatment proscribes in one stroke all of the above enumerated practices.

17. Under the PDA as currently construed, an employer may fire an employee because she is pregnant, as long as the employer persuades the court that the firing is non-"pretextual," i.e., that the employer has or would have treated other disabled employees similarly. Once an employer successfully defends on parity grounds, pregnancy may be deemed "not a factor in any action taken by defendants." Conners v. University of Tenn. Press, 558 F. Supp. 38, 41 (E.D. Tenn. 1982); accord Brown-Weathersby v. Seaway Nat'l Bank, No. 82-C-2351, slip op. (N.D. Ill. May 4, 1983); 
benefits: women employed in unorganized sectors of the economy, receiving low levels of fringe benefits. ${ }^{18}$ Until general benefit levels increase, their situation would appear to be without remedy. According to strict adherents to a parity interpretation of the amendment, the PDA proscribes, as "reverse discrimination,"19 all efforts to accommodate pregnancy in the workplace, whether voluntarily undertaken by an employer, ${ }^{20}$ or mandated by state law. ${ }^{21}$ So construed, the PDA is now inhibiting initiatives to supplement its coverage. ${ }^{22}$

Marafino v. St. Louis County Circuit Court, 537 F. Supp. 206, 211-12 (E.D. Mo. 1982), affd, 707 F.2d 1005 (8th Cir. 1983).

A leading commentator on employment discrimination has observed, "Clearly, if an employer says, 'All pregnant employees will be fired,' there is sex discrimination. It is really no different in effect to say, 'No maternity leaves will be granted."' A. LARSON \& L. LARSON, supra note 15, at 8-31.

18. See Krieger \& Cooney, supra note 15 , at 520-22.

19. See infra note 21.

20. See Barone v. Hackett, 28 Fair Empl. Prac. Cas. (BNA) 1765, 1769 n.4 (D.R.I. 1982) (court holds that PDA requires only comparable treatment, reserving question of whether employer's voluntary provision of unpaid maternity leave discriminates against employees disabled for other cause).

21. See California Fed. Sav. \& Loan Ass'n v. Guerra, 34 Fair Empl. Prac. Cas. (BNA) 562 (C.D. Cal. 1984). The Cal Fed court held that the PDA preempted California law requiring employers to provide pregnant employees unpaid disability leave of up to four months and job reinstatement rights within a reasonable time of their return. The court ruled that California's provision of "preferential reinstatement rights" was "inconsistent with the purpose of Congress in enacting the Pregnancy Discrimination Amendment," and that compliance with state law would subject employers to "reverse discrimination suits under Title VII brought by temporarily disabled males who [did] not receive the same treatment as female employees disabled by pregnancy." Id. at 568.

In Miller-Wohl Co. v. Commissioner of Labor \& Indus., 515 F. Supp. 1264 (D. Mont. 1981), vacated on jurisdictional grounds, 685 F.2d 1088 (9th Cir. 1982), a federal court refused to recognize a similar preemption challenge to Montana's Maternity Leave Act, on the narrow grounds that there was no necessary conflict between federal and state statutes. An employer could amend its leave policy to increase leave for all employees, such that the company would satisfy Montana's maternity leave requirement, without violating the PDA's mandate of comparable treatment. The court recognized, however, that were a disparate impact cause of action available under the PDA, federal and state law would be consistent-both requiring adequate leave for childbearing purposes. $515 \mathrm{~F}$. Supp. at 1267.

The preemption challenge to Montana's law was dismissed on appeal for lack of federal jurisdiction, and the judgment below vacated, 685 F.2d 1088 (9th Cir. 1982). The preemption claim was subsequently raised in state court, where the Supreme Court of Montana ultimately sustained the state's maternity leave requirement as consistent with Title VII, on the grounds that the PDA itself proscribes facially neutral employment policies having a disparate impact on pregnant women. Miller-Wohl's no-leave rule violated both state and federal law, each of which required the provision of adequate leave to pregnant women. Miller-Wohl Co. v. Commissioner of Labor \& Indus., No. 84172, slip. op. (Mont. Dec. 28, 1984). A similar argument has been raised on appeal in the Cal Fed case. See Brief for Amicus Curiae Equal Rights Advocates at 20-29, California Fed. Sav. \& Loan Ass'n v. Guerra, Nos. 84-5843 and 84-5844 (9th Cir. 1984). For additional arguments against preemption, see Krieger \& Cooney, supra note 15, at 522-25, 531-33.

22. Press coverage of the preemption controversy, see supra note 21 , has publicized the potentially negative thrust of the PDA's mandate. See, e.g., Wash. Post, Apr. 5, 1984, at D1, col. 1; N.Y. Times, July 22, 1984, at F1, col. 2. It is not unlikely that the threat of liability has deterred employers and unions from exploring possible accommodations of pregnancy in the workplace. 


\section{B. Construing the PDA Within Title VII}

Those advancing a parity interpretation of the $\mathrm{PDA}^{23}$ err by treating it as an independent statutory enactment, rather than as an amendment to a highly developed statutory scheme. The PDA itself provides no substantive rule to govern pregnancy discrimination claims. Rather, Congress inserted the amendment, section $701(\mathrm{k})$, in the Act's definitional provisions, ${ }^{24}$ where it now functions to supplement the meaning of "sex" within the Act as a whole. ${ }^{25}$ The PDA thus finds substantive force through sections 703(a)(1) and (2), which enumerate the employment practices proscribed under the Act. ${ }^{26}$

As the Court has construed section 703(a), plaintiffs may challenge practices that are discriminatory in intent ("disparate treatment") or effect ("disparate impact"). ${ }^{27}$ The parity standard, which requires that the pregnant employee be treated the same as others on the basis of ability or inability to work, makes dissimilar, or exclusionary, treatment of the pregnant employee actionable under Title VII in accordance with traditional disparate treatment principles. ${ }^{28}$ The parity standard, however, is

23. See supra note 15.

24. Section 701 [42 U.S.C. $\$ 2000 \mathrm{e}$ (1982)] defines a range of terms for the purposes of Title VII, including "person," "employer," "employee," and "industry affecting commerce."

25. The Senate Report states that the "bill . . . does not alter the basic principles of title VII law as regards sex discrimination. Rather, this legislation clarifies the definition of sex discrimination for title VII purposes." S. REP. No. 331, supra note 13, at 5-6. The House Report states: "Pregnancybased distinctions will be subject to the same scrutiny on the same terms as other acts of sex discrimination proscribed in the existing statute." H.R. REP. No. 948, supra note 13, at 4.

26. Section 703(a)(1) makes it unlawful for an employer "to fail or refuse to hire or to discharge ... or otherwise to discriminate . . . with respect to . . . compensation, terms, conditions, or privileges of employment, because of . . . sex." Section 703(a)(2) makes it unlawful for an employer "to limit, segregate, or classify his employees . . . in any way which would deprive or tend to deprive any individual of employment opportunities or otherwise adversely affect his status as an employee, because of . . sex." 42 U.S.C. $\$ 2000 \mathrm{e}-2$ (a) (1982).

27. The Supreme Court distinguished the two causes of action in International Bhd. of Teamsters v. United States, 431 U.S. 324 (1977). The Court observed that claims of disparate treatment may be alleged where

[t]he employer simply treats some people less favorably than others because of their race, color, religion, sex, or national origin. Proof of discriminatory motive is critical, although it can in some situations be inferred from the mere fact of differences in treatment. . .

Claims of disparate treatment may be distinguished from claims that stress "disparate impact." The latter involve employment practices that are facially neutral in their treatment of different groups but that in fact fall more harshly on one group than another and cannot be justified by business necessity. Proof of discriminatory motive, we have held, is not required under a disparate-impact theory.

Id. at $335 \mathrm{n} .15$ (citation omitted).

28. The requirement of similar treatment operates to identify and proscribe exclusionary animus toward pregnancy in the workplace. E.g. "[C]lassifications are in order provided that, in their relationship to each other, they do not discriminate against pregnancy. [A disability policy can classify] provided that, inherently, it does not simply pick out pregnancy and put a fixed and arbitrary limit on that." 123 Cong. REC. 29,659 (1977) (statement of Sen. Javits).

Strictly speaking, the sexes cannot be treated similarly with respect to pregnancy. As a sex-specific trait, pregnancy is in many important respects unlike other (non-sex-linked) conditions that may 
inconsistent with a disparate impact claim. The disparate impact claim allows plaintiffs to challenge facially neutral employment practices, which by definition treat employees "comparably," but nonetheless have an exclusionary impact on the Act's protected classes. ${ }^{29}$ If courts hold a standard of comparable treatment to govern exclusively under the PDA, the amendment will bar a disparate impact cause of action for pregnancy discrimination, rendering the pregnancy discrimination claim inferior in status to all other race- and sex-based claims.

No evidence in the legislative history suggests Congress intended the amendment to have this effect. Rather, that history, analyzed in light of the developments in Title VII doctrine which precipitated the amendment's passage, makes clear that a disparate impact cause of action for pregnancy discrimination not only survived the PDA's enactment, but is fully consistent with its purposes.

\section{The PDA as a Response to Gilbert and Satty}

In General Electric Co. v. Gilbert, ${ }^{30}$ the Supreme Court refused to recognize a pregnancy classification as sex-based. ${ }^{31}$ It thus foreclosed disparate treatment analysis of exclusionary pregnancy policies, requiring plaintiffs to prove that policies incorporating such "facially neutral" classifications had a disparate impact on women generally. ${ }^{32}$ A year later in Nashville Gas Co. v. Satty, ${ }^{33}$ the Court employed disparate impact analysis to invalidate a maternity leave policy requiring forfeit of all accrued seniority. It distinguished Gilbert, observing: "[P]etitioner has not merely refused to extend to women a benefit that men cannot and do not receive,

prove temporarily disabling for an employee, see infra p. 942 . However, the requirement that pregnancy be treated as well as these other, non-sex-linked conditions serves to root out invidious, sexbased employment decisions, the object of disparate treatment analysis.

29. The facially neutral practices that the Supreme Court invalidated in Griggs v. Duke Power Co., 401 U.S. 424 (1971) (employment tests and requirement of high school diploma), and Dothard v. Rawlinson, 433 U.S. 321 (1977) (height-weight requirements), treated all job applicants "comparably," but nonetheless favored whites and males by establishing job requirements in their social and biological image. Unlike disparate treatment doctrine (which presumes those of different race or sex to be similarly situated), disparate impact doctrine recognizes heterogeneity among racial and sexual groups. It proscribes employment practices that discriminate on the basis of such group differences unless strictly justified by business necessity. See Griggs v. Duke Power Co., 401 U.S. at 430 (objective of Title VII to remove barriers that have operated to favor an identifiable group of employees and thus to "freeze' the status quo of prior discriminatory employment practices").

30. 429 U.S. 125 (1976).

31. Id. at 134-35.

32. Id. at 136-40. Acknowledging that disparate impact analysis provided an alternate ground for plaintiff's claim, Justice Rehnquist nonetheless appeared more interested in abolishing the cause of action than in evaluating it. His efforts were soundly repudiated in concurring opinions by Justice Stewart, id. at 146, and Justice Blackmun, id. at 146, and in vigorous dissents by Justice Brennan (joined by Justice Marshall), id. at 153-55, and Justice Stevens, id. at 160-61.

33. 434 U.S. 136 (1977). 
but has imposed on women a substantial burden that men need not suffer." ${ }^{\text {"34 }}$ Although the Court now discerned a tighter nexus between pregnancy and sex, it deemed only some, not all, express pregnancy exclusions to have a disparate impact on women. ${ }^{35}$

It was in this doctrinal context that Congress intervened to amend Title VII. The PDA rectified the inequities of "disparate impact" analysis under Gilbert and Satty by reversing its major premise: that pregnancy classifications were gender neutral, rather than sex-based. As the House Report describes, the PDA's purpose was

to change the definition of sex discrimination in Title VII to reflect the commonsense view and to ensure that working women are protected against all forms of employment discrimination based on sex. By making clear that distinctions based on pregnancy are per se violations of Title VII, the bill would eliminate the need in most instances to rely on the impact approach, and thus would obviate the difficulties in applying the distinctions created in Satty. ${ }^{36}$

Congress did not abolish "the impact approach" but instead restored it to its original purpose: the evaluation of facially neutral employment practices. ${ }^{37}$

34. Id. at 142. The Court sustained another element of defendant's policy, denying women accrued sick pay for childbearing purposes, under the authority of Gilbert. Title VII did not require that "greater economic benefits be paid to one sex or the other "because of their differing roles in the scheme of human existence." Id. Satty thus acknowledged that reproductive difference could form the basis of a disparate impact claim, but only in limited instances.

Satty's "benefits-burden" distinction was criticized by Justice Stevens in his concurrence, id. at 154 n. 4, and by Congress in passing the PDA, see text this page. But the deepest incoherence of the opinion lies not with its distinction between benefits and burdens, but rather with its inconsistent treatment of pregnancy as a sex-specific trait. The Court's reasoning may be summarized as follows: There is no claim of sex discrimination with respect to pregnancy because it is a sex-specific trait; there is a claim of sex discrimination with respect to pregnancy precisely because it is a sex-specific trait. A theory of equality that gives coherent recognition to pregnancy as a sex-specific trait has yet to emerge in the post-amendment period. See infra note 62 and accompanying text.

35. The circuits apparently read Satty as authorizing an ad hoc evaluation of pregnancy discrimination claims, most following Gilbert in rejecting them. Compare Langley v. State Farm \& Casualty Co., 644 F.2d 1124 (5th Cir. 1981) (requirement of immediate notification of pregnancy and mandatory leave on date determined by physician upheld) and In re Southwestern Bell Tel. Co. Maternity Benefits Litig., 602 F.2d 845 (8th Cir. 1979) (limitation on seniority accrual upheld) with Thompson v. Board of Educ., 526 F. Supp. 1035 (W.D. Mich. 1981) (limitation on seniority accrual, notification and medical verification requirements, and mandatory leave policy constitute prima facie violations of Title VII), rev'd on other grounds, 709 F.2d 1200 (6th Cir. 1983).

36. H.R. REP. No. 948, supra note 13 , at 3. By defining policies containing exclusionary pregnancy classifications as per se sex-based, the PDA enabled plaintiffs to challenge them on disparate treatment grounds, where Gilbert and Satty had required they be analyzed in disparate impact terms. As the House Report observes, the amendment eliminates the need to rely on a disparate impact cause of action in such instances. It does not, however, eliminate the cause of action itself.

37. Disparate impact claims under the PDA have been recognized in Abraham v. Graphic Arts Int'l Union, 660 F.2d 811 (D.C. Cir. 1981), Hayes v. Shelby Memorial Hosp., 726 F.2d 1543 (11th Cir. 1984), and Miller-Wohl v. Commissioner of Labor \& Indus., No. 84-172, slip op. (Mont. Dec. 28, 1984); and tentatively considered in Marafino v. St. Louis County Circuit Court, 537 F. Supp. 


\section{Misconstruction of the PDA}

Courts and commentators who insist on a parity construction of the $\mathrm{PDA}^{38}$ find authority for such an interpretation in the amendment's legislative history ${ }^{39}$ and in its second clause, ${ }^{40}$ both of which contain language mandating that the pregnant employee be treated the same as others, on the basis of ability or inability to work. This language is construed restrictively, as stating a substantive principle to govern all pregnancy claims under Title VII. ${ }^{41}$ Such a restrictive construction of the record ignores the doctrinal developments to which Congress' endorsement of parity principles was responsive. It is, moreover, inconsistent with both the language Congress adopted to amend Title VII and the understanding of pregnancy discrimination informing its deliberations.

Congress amended Title VII to repudiate, in unequivocal terms, the exclusionary pregnancy policies at issue in the Gilbert and Satty cases. Recognizing that Title VII principles of comparable treatment would provide full redress to the inequities of such practices, Congress acted to provide plaintiffs the disparate treatment cause of action twice denied them by the Court. ${ }^{42}$ This intent is codified in the PDA's second clause, which functions specifically to reverse Gilbert. ${ }^{43}$ However, as the Supreme

206 (E.D. Mo. 1982), affd, 707 F.2d 1005 (8th Cir. 1983) and Miller-Wohl Co. v. Commissioner of Labor \& Indus., 515 F. Supp. 1264 (D. Mont. 1981), vacated on jurisdictional grounds, 685 F.2d 1088 (9th Cir. 1982). In the main, however, they have been foreclosed by judicial ratification of employer defenses based on a parity interpretation of the amendment. See, e.g., Marafino v. St. Louis County Circuit Court and other cases cited supra note 15. The EEOC identifies parity as the "basic principle" of the PDA, 29 C.F.R. Pt. 1604 app. (1984), but nonetheless maintains a guideline, dating from 1972, barring leave policies having a disparate impact on pregnant women. See infra note 53 .

38. See supra note 15.

39. For example, the House Report states:

[T]his legislation, operating as part of Title VII, prohibits only discriminatory treatment. Therefore, it does not require employers to treat pregnant employees in any particular manner with respect to hiring, permitting them to continue working, providing sick leave, furnishing medical and hospital benefits, providing disability benefits, or any other matter. H.R. 6075 in no way requires the institution of any new programs where none currently exist. The bill would simply require that pregnant women be treated the same as other employees on the basis of their ability or inability to work.

H.R. REP. No. 948, supra note 13, at 4. Accord S. REP. No. 331, supra note 13, at 4. Reassurances of this order are repeated in the legislative history. See infra note 47.

40. For the relevant text of the PDA, see supra note 3.

41. Such a restrictive construction of the PDA preempts both a disparate impact claim to adequate maternity leave and state laws requiring the provision of such leave. See supra note 21.

42. See H.R. REP. No. 948, supra note 13, at 2-3.

43. More specifically, the clause serves to limit the reading of the Bennett Amendment, 42 U.S.C. $\S 2000 \mathrm{e}-2(\mathrm{~h})(1982)$, that the Court advanced in support of its holding in Gilbert. See 429 U.S. 125, 143-45 (1976). (The Bennett Amendment exempts from Title VII's proscription of sex-based wage discrimination pay differentials authorized by the Equal Pay Act, 29 U.S.C. § 206(d) (1982); the Court has since ruled that the Bennett Amendment merely incorporates into Title VII the affirmative defenses of the Equal Pay Act. County of Washington v. Gunther, 452 U.S. 161 (1981).) 
Court has already ruled, this second clause supplements, without limiting, the statutory definition of "sex" set forth in the PDA's first clause.44

The language of this first clause is vital to any interpretation of the amendment. By expressly including "pregnancy" within the meaning of "sex," Congress sought to ensure application of Title VII principles to pregnancy-related claims on the same basis as all other sex-based claims. This larger function of the amendment is confirmed by its location in the definitional provisions of the Act. ${ }^{45}$ Congress' object in reversing Gilbert was to restore and affirm the integrity of Title VII principles ${ }^{46}$ - not to impose a new limiting principle on the pregnancy discrimination claim. ${ }^{47}$

Congress acted to provide women raising pregnancy claims the benefits of full Title VII protection because, unlike the Court, it understood that pregnancy played a central role in the logic of sex-based employment discrimination. As Congress understood, and the Court did not, "[T]he assumption that women will become pregnant and leave the labor force leads to the view of women as marginal workers, and is at the root of the discriminatory practices which keep women in low-paying and dead-end

44. The Supreme Court adopted this construction of the PDA in Newport News Shipbldg. \& Dry Dock Co. v. EEOC, 103 S. Ct. 2622, 2628 n.14 (1983): "The meaning of the first clause is not limited by the specific language in the second clause, which explains the application of the general principle to women employees." The Supreme Court has yet to construe the PDA with reference to the claims of women employees; the Newport News case involved the claim of male employees to maternity-related spousal benefits at levels of coverage equal to those provided female employees.

45. For forceful assertions to this effect, see supra note 25. Had Congress understood its language reversing Gilbert as sufficient to govern all pregnancy claims, it could have simply inserted the PDA's second clause into $\S 703$. Congress did not, because it saw itself as affirming Title VII principles-not altering them.

46. See, e.g., 123 Cong. REc. 29,655 (1977) (statement of Sen. Javits) ("What we are doing is leaving the situation the way it was before the Supreme Court decided the Gilbert case last year."); 124 CoNG. REC. 21,436 (1978) (statement of Rep. Sarasin) ("This bill would restore the interpretation of title VII prior to that decision ...."); accord S. REP. No. 331, supra note 13, at 7-8. In Newport News, the Supreme Court characterized Congress' purpose in passing the PDA as follows: "[A]mending legislation was necessary to reestablish the principles of Title VII law as they had been understood prior to the Gilbert decision." 103 S. Ct. 2622, 2628 (1983). Title VII affords plaintiffs both a disparate treatment and a disparate impact cause of action.

47. Doctrinally consistent resolution of the disability benefits issue presented by Gilbert required no more than comparable treatment. Congressional reassurances to this effect, see supra note 39 , while no doubt helpful in securing the amendment's passage, represent no modification of Title VII principles. The limiting principles for benefits secured by the amendment's passage inhere in Title VII proper, and are not imposed by the PDA itself. As the House Report observes, "We recognize that enactment of H.R. 6075 will reflect no new legislative mandate . . . nor effect changes in practices, costs, or benefits beyond those intended by Title VII of the Civil Rights Act." H.R. REP. No. 948 , supra note 13 , at 3-4.

Congress' preoccupation with parity principles is responsive to the equity issues framed by the Gilbert case, and must be read in that context. There is simply no indication in the legislative history of congressional intention to abrogate a disparate impact cause of action for pregnancy discrimination. Rather, the House Report specifically recognizes its continued existence. See supra p. 936. In addition, both the House and Senate reports give unqualified endorsement to the EEOC's guidelines on pregnancy discrimination, which proscribe leave policies having a disparate impact on women, see infra note 53. H.R. REP. No. 948, supra note 13, at 2; S. REP. No. 331, supra note 13, at 2. 
jobs." ${ }^{18}$ Congress amended Title VII to reverse this cycle of assumptions: to assert that pregnancy is and must be treated as a normal condition of employment. ${ }^{48}$ It saw pregnancy as an integral moment in women's working lives, and was committed to eliminating employment practices that cast them in conflict. ${ }^{\text {so }}$

As it is currently construed, the PDA can only begin to realize Congress' objectives. The requirement of comparable treatment can eliminate overt expressions of animus toward pregnancy, of the type graphically illustrated by Gilbert. But to the extent the workplace remains organized on the basis of male norms, a standard of comparable treatment will in fact perpetuate pregnancy-based exclusions. ${ }^{51}$ It is here that a disparate impact cause of action can play its intended role, scrutinizing employment practices for their latent exclusionary bias. Facially neutral rules that exclude "because of or on the basis of pregnancy," lation of Title VII as amended. Recognition of disparate impact claims under the PDA is essential if the amendment is to realize its primary

48. H.R. REP. No. 948, supra note 13, at 3; cf. 124 CoNG. REc. 21, 440-41 (1978) (statement of Rep. LaFalce) (Gilbert reinforced "outdated argument that women depend on men, and not their jobs, for support").

49. Because analysis of the record to date has tended to focus on the parity principles by which Congress rectified the Court's reasoning in Gilbert, the concerns motivating its extraordinary decision to reverse the Court are frequently overlooked. First among them was the Court's failure to discern the sexual ideology underlying pregnancy discrimination. Congress recognized that the exclusionary treatment of pregnancy expressed a social judgment that woman's reproductive capacity defined and limited her employment capacities, and was, therefore, part of a sexual code implicating all women. It understood that, as a practical matter, securing employment equality for women would require challenging this complex of attitudes at its core. Changing the status of the pregnant employee was deemed essential to changing the employment status of women generally. Senator Williams, Senate sponsor of the PDA, reviewed the sexual disparity in earnings nationwide, observing:

These shocking statistics cannot be made better unless working women are provided effective protection against discrimination on the basis of their childbearing capacity. Testimony . . . has shown that most policies and practices of discrimination against women in the workforce result from attitudes about pregnancy and the role of women who become pregnant which are inconsistent with the full participation of women in our economic system.

Because of their capacity to become pregnant, women have been viewed as marginal workers not deserving the full benefits of compensation and advancement granted to other workers.

123 CoNG. REC. 29,385 (1977) (statement of Sen. Williams). Only when pregnancy is treated as a normal condition of employment will women secure employment equality. It is this vision that informs the PDA's passage. Accord Furnish, supra note 15, at 84 ("The fact that pregnancy is a normal occurrence in the working life of female employees was a basic premise of section $701(\mathrm{k})$. .").

50. See, e.g., 124 CoNG. Rec. 21,442 (1978) (statement of Rep. Myers) ("The right of women to work and their right to bear children cannot be considered mutually exclusive. . . It is time that . . . women are commended for their dual contribution to our society and not penalized for it."); 124 Cong. Rec. 21,439 (1978) (statement of Rep. Corrada) (bill will facilitate women's choice to bear children without facing economic hardship); accord 124 CoNG. REc. 21,440 (1978) (statement of Rep. LaFalce); see also Brown v. Porcher, 502 F. Supp. 946, 956 n.19 (D.S.C. 1980) (PDA "forecloses the possibility that women would have to choose between a role as wage earner or a role as mother"), aff'd in part, 660 F.2d 1001 (4th Cir. 1981), cert. denied, 459 U.S. 1150 (1983).

51. See supra note 17.

52. 42 U.S.C. $\S 2000 \mathrm{e}(\mathrm{k})(1982)$. 
objective: securing a workplace in which pregnancy is, and is treated as, a normal condition of employment.

\section{The Disparate Impact Glaim of Pregnancy DisCRIMINATION}

Two facially neutral practices having an exclusionary impact on the pregnant employee, inadequate leave policies and inflexible job definitions, illustrate the role of disparate impact analysis under the PDA. The discussion of leave policies will examine the equality claim underlying pregnancy discrimination challenges to workplace norms. The discussion of job definitions considers a conjunctive use of disparate treatment and disparate impact claims to secure workplace accommodation of pregnancy under the PDA.

\section{A. The Claim to Adequate Leave}

Since 1972, the EEOC has proscribed leave policies having a disparate impact on pregnant women. ${ }^{53}$ Under the PDA, however, courts have repeatedly dismissed challenges to leave policies inadequate for childbearing on the grounds that they afford employees comparable treatment. ${ }^{54}$ Only two courts have definitively rejected this limiting construction of the amendment. In Abraham v. Graphic Arts International Union, ${ }^{38}$ the D.C. Circuit asserted: "An employer can incur a Title VII violation as much by lack of an adequate leave policy as by unequal application of a policy it does have." ${ }^{\prime 26}$ Plaintiff, fired when her maternity leave exceeded the maximum of ten days leave designated for her position, was held to

53. Codified under a section heading entitled "Employment policies relating to pregnancy and childbirth," the guideline states: "Where the termination of an employee who is temporarily disabled is caused by an employment policy under which insufficient or no leave is available, such a termination violates the Act if it has a disparate impact on employees of one sex and is not justified by business necessity." 29 C.F.R. § 1604.10 (c) (1984).

The period of leave required for purposes of childbearing is normally no more than six weeks. See H.R. REP. No. 948, supra note 13, at 5 . It is to be distinguished from leave for childcare purposes, see supra note 6 .

54. See, e.g., Conners v. University of Tenn. Press, 558 F. Supp. 38 (E.D. Tenn. 1982); BrownWeathersby v. Seaway Nat'l Bank, No. 82-G-2351, slip op. (N.D. Ill. May 4, 1983); $c f$. Marafino v. St. Louis County Circuit Court, 537 F. Supp. 206 (E.D. Mo. 1982) (refusal to hire on the basis of pregnancy upheld where employer would have treated other applicants requesting leave similarly, and where plaintiff failed to prove prima facie case of disparate impact), aff d, 707 F.2d 1005 (8th Cir. 1983). For additional authority adverse to the claim, see infra note 60 .

55. 660 F.2d 811 (D.C. Cir. 1981).

56. Id. at 819 . The D.C. Circuit observed that while a policy setting maximum leave at ten days might be adequate for the needs of most male and female employees holding the job, "any such jobholder confronted by childbirth was doomed to almost certain termination. Oncoming motherhood was virtually tantamount to dismissal. . . . In short, the ten-day absolute ceiling on disability leave portended a drastic effect on women employees of childbearing age-an impact no male would ever encounter." Id. 
have established a prima facie case of disparate impact. ${ }^{57}$ Following Abraham's reasoning, the Supreme Court of Montana held that a state law requiring adequate maternity leave was not preempted by the PDA, as both laws proscribed leave policies having a disparate impact on pregnant women. ${ }^{58}$

The unsympathetic reception accorded the claim to adequate leave cannot simply be ascribed to the prevailing construction of the amendment. It is urged that the pregnant employee has no greater claim to an adequate leave policy than does any other employee facing temporary disability. ${ }^{59}$ Recognizing the claim to adequate maternity leave is held to constitute preferential treatment or reverse discrimination: "Discrimination against males based on pregnancy."

The "preference" entailed in recognizing the claim to adequate maternity leave has yet to receive critical examination. Were the claim to adequate leave recognized, men and women would remain equally unprotected as to all non-reproductive disabilities. ${ }^{61}$ In other words, recognizing the claim creates no sex-based class of "dispreferred," hence effects no sex-based injury. To dismiss the claim to adequate maternity leave on grounds of preference, one must have an equitable objection to accommodating a function specific to women, for which there is no male correlative. ${ }^{62}$

57. Sumary judgment was thus denied, and the case remanded for an adjudication of the employer's defense, that exigencies of the project in which plaintiff was employed (particularly its short term duration) necessitated the challenged leave policy. For a discussion of the prima facie case and business necessity defense under the PDA, see infra Part III.

58. The court did not rely on Abraham's reasoning alone. It reasoned from the text of the PDA itself:

[T] he discharge from her employment of a woman for her pregnancy, without more, is an unlawful practice under Title VII and the PDA. It is a gender-based discrimination. The discharged pregnant woman is not treated the same for all employment-related purposes as all other persons not so affected, obviously, because men cannot be discharged for the same reason. The intent of Title VII and the PDA that women should be treated equally with men on matters of employment means that women cannot be discharged simply because they are pregnant.

Miller-Wohl Co. v. Commissioner of Labor \& Indus., No. 84-172, slip op. at 18 (Mont. Dec. 28, 1984). For discussion of the preemption controversy, see supra note 21 and accompanying text.

59. See Williams, supra note 15, at 196.

60. California Fed. Sav. \& Loan Ass'n v. Guerra, 34 Fair Empl. Prac. Cas. (BNA) 562, 568 (C.D. Cal. 1984) (discussed supra note 21); see also Miller-Wohl Co. v. Commissioner of Labor \& Indus., 515 F. Supp. 1264 (D. Mont. 1981), vacated, 685 F.2d 1088 (9th Cir. 1982) (discussed supra note 21); Brown-Weathersby v. Seaway Nat'l Bank, No. 82-C-2351, slip op. (N.D. Ill. May 4, 1983) ("IPDA] does not mandate affirmative or special maternity leave policies."); $c f$. Fields v. Bolger, 723 F.2d 1216 (6th Cir. 1984) (discussed infra note 68).

61. The class of disabilities unprotected by the claim to adequate leave would include those affecting reproductive organs specific to each sex, e.g., conditions requiring hysterectomy, mastectomy, prostatectomy.

62. As the Supreme Court objected in the pre-amendment period, providing benefits for pregnancy comparable to those afforded non-reproductive disabilities would confer on women "a benefit that men cannot and do not receive." Nashville Gas Co. v. Satty, 434 U.S. 136, 142 (1977). Ironically, the parity standard is now defended on the very grounds on which the Court rejected it in the 
Isolating the legitimate content of the preference objection reveals the fallacy of its central premise. The notion of "preferring" pregnancy to other disabling conditions of employment presupposes a commonality between them that does not obtain, either as a matter of scientific or social understanding. Fundamentally, pregnancy is neither a disability nor a dysfunction, but a normal moment in the human reproductive process specific to women. It is, moreover, a biological difference central to the definition of gender roles, one traditionally believed to render women unfit for employment. $^{63}$ In denying the biological and social specificity of pregnancy, the preference objection obscures the basis of the claim to maternity leave itself.

Leave policies inadequate for childbearing are appropriately challenged under Title VII as they effect sex-based harm. Leave policies that define normal conditions of employment in terms inadequate to accommodate pregnancy define pregnancy as incompatible with employment. ${ }^{64}$ Such policies do not merely embody normative assumptions about the sexes; they perpetuate them. ${ }^{65}$ By withholding the most elemental measure of job

pre-amendment period. By Satty's reasoning, the sex-specificity of pregnancy disentitled women to comparable treatment; under the prevailing interpretation of the amendment, the sex-specificity of pregnancy compels comparable treatment.

Only one court has unequivocally repudiated the preferential treatment objection to provision of adequate maternity leave under the PDA-criticizing those raising preference objections for their failure to recognize pregnancy as a sex-specific trait. See Miller-Wohl Co. v. Commissioner of Labor \& Indus., No. 84-172, slip op. at 23 (Mont. Dec. 28, 1984) (quoting Miller-Wohl Co. v. Commissioner of Labor \& Indus., 515 F. Supp. 1264, 1266 (D. Mont. 1981)).

63. It should be recalled that, until the passage of the PDA, there existed no compelling social analogue between pregnancy and other disabilities. Comprehensive disability benefit plans regularly provided coverage for all forms of employment disabilities-with the sole exception of pregnancy. See Legislation to Prohibit Sex Discrimination on the Basis of Pregnancy: Hearings on H.R. 5055 and H.R. 6075 Before the Subcomm. on Employment Opportunities of the House Comm. on Education and Labor, 95th Cong., 1st Sess. (1977). The singular, exclusionary treatment accorded pregnancy in the disability benefits context was typical of many other employment practices during this period, see supra note 16. At the same time pregnancy was excluded from state unemployment insurance coverage, on the presumption that the pregnant woman was no longer an active candidate in the labor market-a statutory presumption that prevailed until prohibited by federal law. See Federal Unemployment Tax Act, 26 U.S.C. $\$ 3304(a)(12)$ (1982) (no person shall be denied unemployment compensation by state law solely on the basis of pregnancy). See generally Brown v. Porcher, $502 \mathrm{~F}$. Supp. 946, 956 n.19 (D.S.C. 1980) (Civil Rights Act and Federal Unemployment Tax Act amended to resolve conflicts between pregnancy and employment), affd in part, 660 F.2d 1001 (4th Cir. 1981), cert. denied, 459 U.S. 1150 (1983).

64. There is nothing natural in the design of a leave policy that neglects to provide for the contingency of pregnancy. Seventy-five countries, including many developing countries and every industrialized country except the United States, provide some form of statutory maternity leave or parental benefit (insuring all or part of lost wages and health costs associated with pregnancy). Sixteen countries that do not have national health insurance nevertheless provide statutory maternity leaves. S. KAMERMAN, supra note 7, at 15.

65. An exclusion on the basis of pregnancy has powerful normative implications for the emplayee. It confirms that she belongs at home rather than at work, that her status as an employee is subordinate to her role as a mother. A new mother, faced by job loss, is likely to accept the societal judgment implicit in her exclusion and remain at home, particularly when the alternative-searching for a new job, with no income for childcare-is fraught with difficulties. The exclusion of a pregnant 
security from women who would bear children as economically autonomous, rather than dependent, persons ${ }^{66}$ such leave policies penalize any woman who defies conventional sex roles. Such policies reinforce, for employer and employee alike, the assumption that a woman's reproductive role defines and limits her productive role. ${ }^{67}$ The plaintiff challenging an inadequate leave policy does not seek "preferential treatment"; rather, she seeks recognition-in the most limited of terms-that parenting is compatible with employment, for women as well as men.

\section{B. Challenging Inflexible Job Definitions}

A second employment practice susceptible to disparate impact challenge under the PDA is the inflexible job description. An employer may define a job in such a way that pregnant employees in general good health are unable to perform some of its tasks ${ }^{68}$-or are deemed so by the employer. ${ }^{69}$ The employer who requires that an employee meet all qualifications in a particular job description, without exploring such modifications

employee is thus likely to result in a lengthy disruption of her labor force participation, with longterm effects on her employment status and earning capacity. See S. REP. No. 331, supra note 13, at 6 ("Exclusionary pregnancy] policies have long-term effects on the careers of women and account in large part for the fact that women remain today primarily in low-paying, dead-end jobs.").

66. In $1960,27 \%$ of married women were in the labor force; by 1982 , that figure had risen to $56 \%$. The employment rate for single mothers (unmarried, divorced, and widowed) has risen from $59 \%$ in 1970 to $67.7 \%$ in 1982. S. KAMERMaN, supra note 7, at 7. Between 1977 and 1982, labor force participation for mothers of children under one year of age increased from $32 \%$ to $42 \%$. Id. at 12.

67. As long as leave policies remain inadequate for childbearing, and thus result in pregnancybased terminations, women's transient employment status must continue to factor in the daily calculations of employer and employee alike. Such policies thereby implicate women's employability as a class.

68. An example is provided by the recent case of Fields v. Bolger, 723 F.2d 1216 (6th Cir. 1984). There a postal service mail handler early in the term of her pregnancy informed her supervisor that she could lift only 35-40 pounds in weight. Because mail handlers of her job classification were defined as capable of lifting 70 pounds in weight, the court sustained the post office in its decision to place her on unpaid leave.

The job description at issue in Bolger is susceptible to disparate impact challenge. Accommodation is likely to prove feasible where, as here, the job description defines the maximum, rather than typical, exertion required for the job. The feasibility of modifying job tasks in this instance is confirmed by the fact that the employer in Bolger provided alternate light duty assignments for employees injured on the job, although such assignments were not guaranteed to employees temporarily disabled for other cause. It was, however, the existence of this policy that led the Sixth Circuit to sustain the exclusion: "Nothing in Title VII compels an employer to prefer for alternative employment an employee who, because of pregnancy, is unable to perform her full range of duties." $723 \mathrm{~F} .2 \mathrm{~d}$ at 1220 . (While the case was decided under pre-amendment law, a court committed to a parity interpretation of the PDA would have reached the same result. Compare, however, the EEOC's position, discussed infra note 70.)

69. See, e.g., Hayes v. Shelby Memorial Hosp., 726 F.2d 1543 (11th Gir. 1984) (pregnancy disqualifies women for position of radiologist on fetal hazards grounds); Harriss v. Pan American World Airways, 649 F.2d 670 (9th Cir. 1980) (pregnancy incompatible with position of flight attendant on customer safety grounds). 
or recombinations of tasks and duties as would enable a generally fit pregnant employee to continue working, will force her into premature leave, or unemployment. The failure to explore feasible accommodations does not appear as an exclusion of the pregnant employee from the workplace-but it operates in practice to that effect. ${ }^{70}$

Job definitions most urgently require disparate impact analysis in those instances where an employer determines that pregnancy disqualifies women for employment. Under the PDA, courts continue to ratify pregnancy-specific exclusions on customer safety ${ }^{71}$ and fetal hazards grounds. ${ }^{72}$ For example, in Harriss v. Pan American World Airways, ${ }^{73}$ the Ninth Circuit upheld a "stop work" policy requiring pregnant employees to put themselves on unpaid maternity leave within twenty-four hours of learning of pregnancy (with failure to comply considered a "voluntary resignation"). ${ }^{74}$ The court accepted the customer safety rationale advanced by the airline without rigorously analyzing it in accordance with parity principles. ${ }^{75}$ At no point did it consider whether restructuring plaintiffs' job tasks to include ground functions might have satisfied the employer's alleged safety concerns, ${ }^{76}$ with less injury to its predominantly

70. The series of questions and answers developed by the EEOC to guide implementation of the PDA strictly applies parity principles, equivocating only with respect to the question of job modification. Question 5 asserts that an employer must modify job tasks for the pregnant employee in need of accommodation to the same extent that an employer would for employees disabled for other cause. Question 12, however, departs from comparative analysis. In discussing the obligation of an employer to hire a pregnant applicant medically unable to perform all of a job's tasks, the EEOC asserts: "An employer cannot refuse to hire a women [sic] because of her pregnancy-related condition so long as she is able to perform the major functions necessary to do the job." 29 C.F.R. Pt. 1604 app. (1984) (emphasis added). This is the Commission's sole departure from parity concepts in the 37 questions it answers.

71. Levin v. Delta Air Lines, 730 F.2d 994 (5th Cir. 1984); Harriss v. Pan American World Airways, 649 F.2d 670 (9th Cir. 1980).

72. Wright v. Olin Corp., 697 F.2d 1172 (4th Cir. 1982).

73. 649 F.2d 670 (9th Cir. 1980).

74. Id. at 673,676-77. Plaintiffs challenged two additional elements of the policy, a "start work" rule forbidding employees to return to work until 60 days after delivery, and a rule denying accrual of seniority after the first 90 days of leave. Both claims were remanded for further consideration.

75. But see id. at 679 (Schroeder, J., dissenting) (fact that Pan American regulated employment fitness of flight attendants only with respect to risks of pregnancy, and no other physical disability, undermines persuasiveness of customer safety rationale).

76. Although courts have consistently sustained pregnancy "stop work" policies such as Pan American's on customer safety grounds, see, e.g., Levin v. Delta Air Lines, 730 F.2d 994 (5th Cir. 1984); Burwell v. Eastern Air Lines, 633 F.2d 361 (4th Cir. 1980), cert. denied, 450 U.S. 965 (1981), there is good reason to presume the airlines have acted out of concern for their (male) passengers' supposed sexual satisfaction rather than safety. See Wilson v. Southwest Airlines Co., 517 F. Supp. 292 (N.D. Tex. 1981) (female "sex appeal" not bona fide occupational qualification for job of flight attendant, even where airline advertises its services through "love" campaign). Until barred by Title VII, the airlines originally hired only female flight attendants, and defended this policy on the basis of "customer preference." See Diaz v. Pan American World Airways, 442 F.2d 385 (5th Cir.) (superior performance of female flight attendants in providing "personalized service and, in . . . making flights ... pleasurable" insufficient to constitute a bona fide occupational qualification), cert. denied, 404 U.S. 950 (1971). They hired young single women, automatically dismissing any flight attendant who married. See Sprogis v. United Air Lines, 444 F.2d 1194 (7th Cir.), cert. denied, 404 


\section{female workforce. ${ }^{77}$}

Where, as in Harriss, an employer alleges pregnancy-specific reasons for an exclusionary policy, the inflexible job description supporting the policy can be challenged by advancing disparate treatment and disparate impact claims in the alternative. If an employer defeats plaintiffs' disparate treatment claim by proving sex a bona fide occupational qualification ("bfoq") ${ }^{28}$ for the job as defined, plaintiffs can then challenge the job definition supporting the exclusion on disparate impact grounds. ${ }^{79}$

Such a conjunctive use of disparate treatment and disparate impact doctrine was recently authorized by the Eleventh Circuit in Hayes v. Shelby Memorial Hospital..$^{80}$ There an employer fired a radiologist in her second month of pregnancy, claiming that her job posed a risk of fetal harm which justified the exclusion. The Hayes court ruled that an employer seeking to exclude a pregnant woman pursuant to a fetal hazards policy ${ }^{81}$

\section{U.S. 991 (1971).}

To date only one court has acknowledged the underlying sexual logic of the airlines' maternity policies, its findings reversed on appeal. Burwell v. Eastern Air Lines, 458 F. Supp. 474, 499-502 (E.D. Va. 1978), rev'd in part, 633 F.2d 361 (4th Cir. 1980), cert. denied, 450 U.S. 965 (1981). In the main, courts have declared the airlines' "preference" for women to immunize them from allegations of sex discrimination, see infra note 104, and have explicitly refused to take legal cognizance of the larger design of the airlines' employment practices in evaluating pregnancy discrimination claims, see EEOC v. Delta Air Lines, 485 F. Supp. 1004, 1007 (N.D. Ga. 1980).

77. The experience of Delta Air Lines suggests the feasibility of such an arrangement. Delta originally held either pregnancy or marriage to be grounds for firing. Subsequently, it adopted an unpaid leave policy containing "stop work" provisions similar to Pan American's, which it replaced, of its own accord, in 1974 with a policy permitting pregnant flight attendants to transfer to ground positions. See Levin v. Delta Air Lines, 730 F.2d 994, 996 (5th Gir. 1984). Despite Delta's own demonstration of its capacity to accommodate the pregnant employees it deemed unfit to fly, its "stop work" policy was held not to violate Title VII. Id. at 1001-02.

78. Sex-based employment policies can be defended only on the grounds that sex is a bona fide occupational qualification (bfoq) for the job. See 42 U.S.C. $\S 2000 \mathrm{e}-2$ (e) (1982). According to the Supreme Court, the bfoq defense is to remain "an extremely narrow exception" to Title VII's prohibition against sex-based employment decisionmaking. Dothard v. Rawlinson, 433 U.S. 321,334 (1977). In the pregnancy context, the defense would require that an employer meet high standards of proof that pregnancy peculiarly disqualified "all or substantially all women" for employment, in a fashion distinct from other (non-sex-linked) physical conditions. Weeks v. Southern Bell Tel. \& Tel. Co., 408 F.2d 228, 235 (5th Cir. 1969).

79. This is precisely what makes recognition of disparate impact claims significant in such litigation. The bfoq defense presumes the integrity of a particular job description; the disparate impact claim entitles plaintiffs to challenge it.

80. 726 F.2d 1543 (11th Cir. 1984).

81. The leading article on fetal hazards regulation under the PDA is Williams, Firing the Woman to Protect the Fetus: The Reconciliation of Fetal Protection with Employment Opportunity Goals under Title VII, 69 GEo. L.J. 641 (1981). As Williams' review of the scientific literature suggests, toxic substances can affect the normal development of the fetus (a) prior to conception, by damaging male or female reproductive cells, or (b) subsequent to conception, acting directly upon the fetus in utero. Id. at 655-60. Thus, fetal hazards regulation directed exclusively at women may be premised on traditional assumptions concerning woman's primary reproductive role, rather than a scientific understanding of the basis of fetal injury. Id. at 660-61. Williams argues that policies directed exclusively at women can survive Title VII analysis only if shown to be "neutral" in their objective of protecting employee offspring, i.e., that the workplace in fact poses no risk to the offspring of male employees. Id. at 687-88.

Commentators dissenting from Williams' analysis argue that no sex-based fetal hazard policy can 
was first required to prove the risk sex-based in fact. ${ }^{82}$ Were such a defense successfully established, the question of Title VII liability would not be resolved, but reframed. The policy's exclusive effect on women provided "the employee ... an automatic prima facie case of disparate impact."

Once the underlying disparate impact claim is recognized, Title VII doctrine allows employers to defend the challenged practice as a business necessity. Plaintiffs, however, may rebut this defense by demonstrating less exclusionary means of implementing the employer's policy. ${ }^{84}$ Thus, consistent with Title VII precedent, Hayes held that plaintiff was entitled to demonstrate that job restructuring constituted an alternate method of minimizing fetal risk having a lesser exclusionary impact on pregnant employees. ${ }^{85}$ As the Hayes court recognized, disparate impact doctrine imposes a duty of reasonable accommodation upon the employer-one of heightened significance in view of pregnancy's historic exclusion from the workplace. ${ }^{88}$

survive scrutiny under Title VII, as amended. An employment policy that expressly excludes on the basis of sex (or pregnancy) is sex-based, regardless of its objectives; and all defenses to sex-based employment policies under the Act concern job performance and customer safety-not fetal risk. See, e.g., Furnish, supra note 15; Howard, Hazardous Substances in the Workplace: Implications for the Employment Rights of Women, 129 U. PA. L. Rev. 798 (1981).

82. 726 F.2d 1543, 1548 (11th Cir. 1984).

83. Id. at 1552 . The court's derivation of the disparate impact claim is worthy of closer scrutiny. Following Williams, supra note 81, the court adopted an expansive definition of a neutral employment policy. It deemed a sex-based policy "neutral" where an employer could show that workplace hazards required only the regulation of women's employment in order to provide equal protection to the offspring of all employees. Id. at 1548. This showing of "neutrality" is the functional equivalent of a bfoq defense (the employer justifies use of sex-based employment criteria by proving they serve sex-neutral policy objectives), with one critical distinction: Once the employer proves the disputed policy "neutral," plaintiffs are entitled to challenge it on disparate impact grounds. The net effect of the analytical framework adopted in Hayes is to allow plaintiffs to challenge fetal hazards policies by advancing disparate treatment and disparate impact claims in the alternative.

84. For a discussion of the business necessity doctrine under the PDA, see infra Part III.

85. Less exclusionary alternatives discussed by the Hayes court included (a) assigning plaintiff other duties within the hospital and (b) rearranging plaintiff's duties within her own department. 726 F.2d at 1553-54. Courts have held disparate impact doctrine to require evaluation of less exclusionary alternatives in two similar cases governed by pre-amendment law. Fancher v. Veterans Admin. Medical Center, 507 F. Supp. 124 (E.D. Ark. 1981) (temporary reassignment); Zuniga v. Kleburg County Hosp., 692 F.2d 986 (5th Cir. 1982) (temporary leave of absence).

In recognizing plaintiff's underlying disparate impact claim, the Eleventh Circuit established a precedent whose significance may be appreciated in light of the Fifth Circuit's ruling in Levin v. Delta Air Lines, 730 F.2d 994 (5th Cir. 1984). Plaintiff flight attendants in the Levin case were excluded from employment during the full term of pregnancy, in accordance with an airline "stop work" policy. The Levin court ruled that once the airline made out its bfoq defense on customer safety grounds, "it would be unreasonable to place on it the burden of taking extraordinary measures to cushion the blow for affected employees," 730 F.2d at 1001, even though Delta's subsequent adoption of a policy providing alternate ground duty assignments had proven the feasibility of job restructuring.

86. The Hajes court summarized the implications of its decision: "[T]o avoid Title VII liability for a fetal protection policy, an employer must adopt the most effective policy available, with the least discriminatory impact possible. To require any less would be to return to the days of Muller $v$. Oregon." 726 F.2d 1543, 1553 (11th Cir. 1984). The Hajes court is thus the first to recognize the historical basis of pregnancy discrimination, and its relevance to the adjudication of claims under the 


\section{Litigating a Disparate Impact Glaim}

The pregnancy discrimination challenge to exclusionary leave policies or job definition practices rests on traditional Title VII principles. In applying these principles courts must nonetheless ensure that disparate impact litigation under the PDA remains responsive to the logic of the pregnancy discrimination claim.

\section{A. Plaintiff's Prima Facie Case}

To establish a prima facie case of disparate impact under the PDA, plaintiffs must demonstrate the impact of a challenged practice on the class of pregnant women, rather than women generally. ${ }^{87}$ Demonstrating impact in this fashion is consistent with the amendment's first clause, which provides that a practice that excludes "because of or on the basis of pregnancy"8s excludes on the basis of sex. It is, furthermore, consistent with the understanding of pregnancy discrimination that informed Congress' decision to amend Title VII. ${ }^{89}$ All women are implicated in the exclusion of the pregnant employee; ${ }^{90}$ the pregnant woman therefore represents the class for disparate impact purposes.

Demonstrating the impact of a particular job definition or leave policy on an individual pregnant employee may, however, be insufficient to establish disparate impact for Title VII purposes. Because the disparate impact claim is one defined with reference to group membership, ${ }^{91}$ plaintiff's prima facie case must establish that the challenged practice embodies

PDA. See infra notes $110-11$ and accompanying text.

87. The Court's application of disparate impact doctrine in the pre-amendment period demonstrates the practical significance of this analytical distinction. In Gilbert, the Court suggested that the impact of a practice excluding on the basis of pregnancy required evaluation with respect to women as a class, thereby diffusing its legally cognizable effects. See 429 U.S. at 137-40 ("no proof that the package is in fact worth more to men than to women"). In Satty, however, the Court focused specifically on the practice's impact on pregnant women. See 434 U.S. at 142 (employer may not "deprive [women] of employment opportunities because of their different role"); see also id. at 144 (holding in Gilbert "did not depend on . . . evidence" of plan's value to women as a class). The D.C. Circuit in Abraham v. Graphic Arts Int'l Union, 660 F.2d 811 (D.C. Cir. 1981), quoted supra note 56, has adapted Satty's approach to PDA disparate impact claims, as has the Supreme Court of Montana, see supra note 58. An analytical framework modeled after Gilbert was, however, suggested in Marafino v. St. Louis County Circuit Court, 537 F. Supp. 206, 213 (E.D. Mo. 1982), affd, 707 F.2d 1005 (8th Cir. 1983).

88. 42 U.S.C. $\$ 2000 \mathrm{e}(\mathrm{k})(1982)$.

89. See supra note 49 and accompanying text.

90. Most obviously, the situation of the pregnant employee is representative of that of all other female employees, when pregnant. Just as importantly, policies affecting pregnant employees will ultimately affect the status of all women in the workplace. See 123 CoNG. REC. 29,385 (1977) (statement of Sen. Williams) ("TT]he overall effect of discrimination against women because they might become pregnant, or do become pregnant, is to relegate women in general, and pregnant women in particular, to a second-class status with regard to career advancement and continuity of employment and wages.").

91. See, e.g., International Bhd. of Teamsters v. United States, 431 U.S. 324, 335 n.15 (1977); Furnco Construction Corp. v. Waters, 438 U.S. 567, 582 (1978) (Marshall, J., concurring in part); 
a norm likely to have an exclusionary impact on pregnant women as a class. ${ }^{82}$ This determination in some instances may be made as a matter of judicial notice; ${ }^{93}$ but in others will require the development of new evidentiary standards for disparate impact purposes. ${ }^{94}$

\section{B. The Business Necessity Defense}

Under Title VII, an employer is entitled to rebut plaintiff's prima facie case by demonstrating business necessities-considerations of safety or efficiency-that justify a challenged practice despite its exclusionary impact. ${ }^{95}$ Plaintiffs then have the opportunity to identify less exclusionary means by which an employer might effectuate the claimed business purposes. $^{98}$ Litigation of defenses to disparate impact claims will therefore

Connecticut v. Teal, 457 U.S. 440, 457 (1982) (Powell, J., dissenting); B. Schler \& P. Grossman, EMPLOYMENT Discrimination LAw 1324 (1984). The requirement of class impact does not, however, operate to preclude claims brought by individual plaintiffs, where proof of group impact can be determined as a matter of judicial notice or general statistical inference. See Mitchell v. Board of Trustees, 599 F.2d 582, 585 n.7 (4th Cir.) (requiring statistical proof involving significant sample of actual applications of policy would always preclude the claim of first "impactee," and may be inappropriate where individual brings disparate impact claim), cert. denied, 444 U.S. 965 (1979). The cases cited infra note 93 suggest the frequency with which disparate impact claims are raised by individual plaintiffs.

92. In practice, such a requirement will select as a workplace norm the exigencies of a pregnancy without significant medical complication.

93. See, e.g., Nashville Gas Co. v. Satty, 434 U.S. 136, 142 (1977); Abraham v. Graphics Art Int'l Union, 660 F.2d 811, 819 (D.C. Cir. 1981); Dothard v. Rawlinson, 433 U.S. 321, 330 (1977); Mitchell v. Board of Trustees, 599 F.2d 582, 585 n.7 (4th Cir.), cert. denied, 444 U.S. 965 (1979). But cf. Marafino v. St. Louis County Circuit Court, 537 F. Supp. 206, 213 (E.D. Mo. 1982) (court "cannot simply imagine a disparate impact"), affd, 707 F.2d 1005 (8th Cir. 1983).

94. In developing a prima facie case, plaintiffs could introduce into evidence such relevant statistics as may be available from government, medical, or other expert sources, much as one establishes proof of exclusionary impact in other disparate impact cases. See, e.g., Dothard v. Rawlinson, 433 U.S. 321, 330 (1977) (statistics documenting aggregate height-weight differences on basis of sex nationally); Hazelwood School Dist. v. United States, 433 U.S. 299 (1977) (census figures).

95. See Dothard v. Rawlinson, 433 U.S. 321, $331 \mathrm{n} .14$ (1977) ("[A] discriminatory employment practice must be shown to be necessary to safe and efficient job performance to survive a Title VII challenge."); Robinson v. Lorillard, 444 F.2d 791, 798 (4th Cir.) (widely-cited elaboration of this standard), cert. denied, 404 U.S. 1006 (1971).

The "job-relatedness" test employed by courts to scrutinize applicant testing procedures would appear to be an inappropriate formulation of the business necessity doctrine in other contexts. In the applicant testing context it functions as a "rigorous standard," Washington v. Davis, 426 U.S. 229, 247 (1976); in any other context "job-relatedness" is a vague standard, easily invoked to ratify existing employment practices. The better approach would be to scrutinize a challenged practice in light of the core values of safety and efficiency upon which business necessity doctrine rests. See Williams, supra note 81 , at $689-93$.

96. The Supreme Court formulated the terms of plaintiffs' rebuttal in Albemarle Paper Co. v. Moody, 422 U.S. 405, 425 (1975), a case involving a disparate impact challenge to applicant testing procedures: "If an employer does then meet the burden of proving that its tests are 'job-related,' it remains open to the complaining party to show that other tests or selection devices, without similarly undesirable racial effect, would also serve the employer's legitimate interest in 'efficient and trusty workmanship." "The Sixth Circuit has outlined evidence that a court should consider in evaluating the merits of plaintiffs' rebuttal:

Certainly any subsequent practices adopted by the company would be relevant. The hiring

policies of comparable businesses might also shed some light on what constitutes a feasible 
focus on two considerations: the cost of alternate practices, and the infringement on management prerogatives entailed in implementing them.

Business necessity doctrine recognizes cost as a legitimate, but not dispositive, factor in the evaluation of employer defenses. ${ }^{97}$ The presumption against defenses based on cost per se should assume particularly strong form under the PDA. Congress' action in amending Title VII-reversing an industry-wide practice of exempting pregnancy from disability benefits coverage-evidences a clear commitment to this principle in the pregnancy context. ${ }^{98}$ Where an employer raises cost objections to the adoption of alternate practices, standard business practice with respect to the accommodation of non-reproductive disabilities should provide a reasonable benchmark for evaluating the defense. ${ }^{8 \theta}$

Although rarely described as such, plaintiff's rebuttal to the employer's business necessity defense imposes a duty of reasonable accommodation on the employer, ${ }^{100}$ a duty which cannot be avoided by simple invocation of management prerogative. As courts evaluate the less exclusionary alternatives plaintiffs have suggested, they must establish reasonable parameters of accommodation in accordance with the larger mandate of the PDA: that pregnancy is presumptively a normal condition of employment. ${ }^{101}$

alternative. Of course, the marginal cost of another hiring policy and its implications for public safety are factors which should not be omitted from consideration.

Chrisner v. Complete Auto Transit, 645 F.2d 1251, 1263 (6th Cir. 1981).

97. See Robinson v. Lorillard Corp., 444 F.2d 791, 799 n.8 (4th Cir.) (in "determining the existence of business necessity, dollar cost alone is not determinative"), cert. denied, 404 U.S. 1006 (1971); $c f$. Wilson v. Southwest Airlines Co., 517 F. Supp. 292, 304 (N.D. Tex. 1981) (loss of competitive advantage does not constitute business necessity insofar as it would limit Title VII coverage to financially successful enterprises); Bush v. Lone Star Steel Co., 373 F. Supp. 526, 532-33 (E.D. Tex. 1974) ("expense involved in changing from a discriminatory system" does not constitute "business necessity that would justify the continuation of . . . discrimination").

98. Congress received extensive testimony on the cost of including pregnancy in disability benefits programs, with estimates varying by as much as $400 \%$. The House adopted an estimate of almost 200 million dollars. H.R. Rep. No. 948, supra note 13, at 9. The Senate Report, acknowledging the difficulties of ascertaining cost projections, nonetheless asserts "even a very high cost could not justify continuation of the policy of discrimination against pregnant women which has played such a major part in the pattern of sex discrimination in this country." S. REP. No. 331, supra note 13, at 11. See also Hayes v. Shelby Memorial Hosp., 726 F.2d 1543, 1552 n.15 (11th Gir. 1984) (where fetal hazard policy is challenged under PDA, business necessity defense allowed on grounds of safety, not cost of potential liability).

99. Cf. Chrisner v. Complete Auto Transit, 645 F.2d 1251, 1263 (6th Cir. 1981) (policies of comparable businesses may "shed . . . light on what constitutes a feasible alternative"). Reference to standard business practice outside the pregnancy context should eliminate the bias that commonly informs thinking about pregnancy in the workplace. Cost concerns should, moreover, be evaluated in light of the presumption that all industry competitors are in compliance with statutory mandate. $C f$. Wilson v. Southwest Airlines Co., 517 F. Supp. 292, 304 (N.D. Tex. 1981).

100. This duty of reasonable accommodation is implicit in the terms of plaintiff' rebuttal, see supra note 96. It finds practical illustration in the Abraham and Hayes cases, discussed supra Part II. Frug, supra note 6, at 71, has suggested that the issue of feasible accommodations is the crux of the business necessity defense: "Alternative practices must be usable in lieu of the challenged practice for the plaintiffs to succeed in their case; conversely, alternative practices must not be available for an employer to succeed in his defense."

101. See supra note 49 . It is impossible to state a per se rule to guide courts in determining the 


\section{Pregnancy Discrimination in the Sex Segregated WORKPLACE}

The American workforce remains sexually segregated. Half of all working women work in occupations that are over $70 \%$ female; more than one-quarter work in jobs that are $95 \%$ or more female. ${ }^{102}$ Although Title VII doctrine has enabled women to challenge their exclusion from male-dominated job categories, it has proven less effective in combatting the sex discrimination faced by women who remain isolated in traditionally "female" occupations.

Litigation of comparable worth claims is now focusing attention on sexbased pay discrimination as it operates within the female-dominated job category. ${ }^{103}$ Pregnancy discrimination in the female-dominated job category requires similar scrutiny. Although courts applying pre-amendment

scope of reasonable accommodation. Where plaintiff shows that alternate, less exclusionary practices are readily available, the employer's business necessity objections are sometimes characterized as a "pretext" for discrimination. See, e.g., Albemarle Paper Co. v. Moody, 422 U.S. 405, 425 (1975); Levin v. Delta Air Lines, 730 F.2d 994, 1001 (5th Cir. 1984). Plaintiffs, however, are not required to prove the employer's objections pretextual, but of. Levin, 730 F.2d at 1001, as proof of intent is irrelevant to disparate impact litigation, see International Bhd. of Teamsters v. United States, 431 U.S. 324, 335 n.15 (1977). The disparate impact inquiry is better conceptualized in the following terms: Have prevailing societal norms resulted in the adoption or maintenance of exclusionary practices, or in an indifference to their exclusionary impact? Where feasible alternatives are available, their existence illuminates latent social bias. For analysis of the claim in similarly socio-historical terms, see Hayes v. Shelby Memorial Hosp., 726 F.2d 1543, 1553 (11th Cir. 1984) (pregnancy); Griggs v. Duke Power Co., 401 U.S. 424, 429-30 (1971) (race).

102. Blumrosen, Wage Discrimination, Job Segregation and Women Workers, 6 Women's RTS. L. REP. 19, 22 n.7 (1980). It has been estimated that, for 1976, about two-thirds of nonminority women would have had to change occupations in order to achieve an occupational distribution identical with that of nonminority males; figures ranged higher for minority women. U.S. COMM'N ON Givil Rights, Social Indicators of Equality for Minorities and WOMEN 42 (1978).

Sex segregation by occupation remained at constant levels during the period 1900-1960, and in 1960 exceeded the degree of job segregation by race. Gross, Plus Ca Change. . .? The Sexual Structure of Occupations Over Time, 16 Soc. PRoBs. 198, 202 (1968). Although women have moved into male dominated occupations over the century (e.g. manufacture and banking), "the tendency . . . has been for men to move out . . . thus reconstituting the segregation." C. DEGLER, AT ODDS: WOMEN AND the Family in AMerica From the Revolution to the Present 424 (1984); accord J. Matthaei, AN Economic History of Women in AMERica: Women's Work, the Sexual DIvision OF LABOR, AND THE DEVELOPMENT OF CAPITALISM 218 \& n.58 (1982). A particularly pointed example is provided by the feminization of clerical work. See id. at 220-23.

103. While traditional pay discrimination claims have entailed comparison of wages paid to employees performing the same or substantially similar work, the comparable worth theory seeks to prove pay discrimination by establishing that male and female employees performing jobs of different content are nonetheless performing work of "comparable worth" to their employers, despite the pay differential between them (e.g. "light" custodian, "general" custodian; secretary, truck driver). In pure form, a plaintiff attempting to prove a comparable worth claim would submit a job evaluation study (of the type commonly used by large employers) to establish that pay differentials between "male" and "female" job classifications were traceable to sex discrimination rather than job worth. However, most cases litigated to date have involved claims that an employer knowingly deviated from the terms of its own job evaluation study in setting wage rates for male- and female-dominated job classifications. See generally Bureau of Nat'l Affairs, The Comparable Worth Issue: A BNA SPECIAL REPORT (Nov. 7, 1981).

The Supreme Court has held that, under Title VII, women in a female-dominated job classification may raise claims of wage discrimination, even where the absence of men performing substantially 
law have viewed the claim with skepticism, ${ }^{104}$ under the amendment it warrants reevaluation. Prevailing parity principles should enable women to challenge overt exclusions on the basis of pregnancy, regardless of their numbers in the workplace. It remains to be determined whether, under the PDA, women in a female-dominated job category can raise a disparate impact challenge to facially neutral practices that exclude on the basis of pregnancy.

Women should not be denied the benefits of full statutory protection because of their segregation in the workplace. The sexual stratification of the American workforce is neither accidental, nor the simple expression of conventional role preferences. Throughout the century sex segregation in employment was both precipitated and exacerbated by public and private regulation-frequently justified with reference to women's reproductive role. ${ }^{105}$ The assumption that pregnancy is incompatible with employment remains fiercest in precisely those sectors of the workforce where women

similar work would preclude proof of discrimination under the Equal Pay Act, 29 U.S.C. § 206(d) (1982). County of Washington v. Gunther, 452 U.S. 161 (1981). The Court, however, specifically reserved the question of whether such a pay discrimination claim required a showing of intentional discrimination. Id. at 166, 180-81. The lower courts have moved cautiously in recognizing claims of comparable worth, absent some showing of intentional discrimination. See, e.g., AFSCME v. Washington, 578 F. Supp. 846 (W.D. Wash. 1983) (pay structure of state employment system violated Title VII on disparate treatment and disparate impact grounds, where state's own job evaluation study showed women consistently underpaid); Taylor v. Charley Bros., 25 Fair Empl. Prac. Cas. (BNA) 602 (W.D. Pa. 1981) (where employer was found intentionally to have segregated assembly jobs by sex, job evaluation constituted admissible evidence to prove wage discrimination in violation of Title VII); $c f$. Spaulding v. University of Wash., 740 F.2d 686 (9th Cir.) (where no intentional discrimination proven, showing of wage disparity between comparable jobs insufficient to establish prima facie case of disparate impact), cert. denied, 105 S. Ct. 511 (1984).

104. The fact that an employer hired only women has been held to bar disparate impact claims of pregnancy discrimination under pre-amendment law. See, e.g., EEOG v. Delta Air Lines, 485 F. Supp. 1004, 1007 (N.D. Ga. 1980) (because airline policy of terminating pregnant flight attendants overlapped period when airline hired only female flight attendants, termination policy "was discrimination against pregnancy but was not and could not be sexual discrimination against women"); James v. Delta Air Lines, 571 F.2d 1376, 1377-78 (5th Cir.) (no sex discrimination in policy imposing seniority forfeiture on pregnant flight attendants where airline hired no male flight attendants), cert. denied, 439 U.S. 864 (1978). Courts have dismissed pregnancy discrimination claims raised by women in female job categories by defining sex discrimination narrowly, as requiring a preference between similarly situated men and women, or by requiring such an instance of comparative preference as evidence of discrimination. The underlying objection to recognizing such claims would seem to be that an employer of an all-female workforce has evidenced a "preference" for women, rather than an exclusionary animus toward them. Similar objections have been raised in a case litigated under the PDA. See Harvey v. YWCA, 533 F. Supp. 949, 954 (W.D.N.C. 1982) (where directors and nearly all employees were female, court found it difficult to see how plaintiffs could establish sex discrimination). However, the sex-composition of plaintiff's job classification played no role in the determination of impact in either the Abraham or Hajes cases, discussed supra Part II.

105. For a discussion of this pronatalist regulatory tradition, see infra notes 110-11 and accompanying text. For a discussion of its role in exacerbating job segregation, see W. ChAFE, ThE AMERICAN Woman 124-25 (1972); C. DegleR, supra note 102, at 401-04; A. Kessler-HarRis, Out to Work: A History of Wage-Earning Women IN tHe UnIted States 193-95 (1982). KesslerHarris documents organized labor's advocacy of pronatalist regulation of women's employment to protect male jobs and wages. Id. at 201-05. 
have been segregated. ${ }^{106}$ The sex segregation of the workplace should not be invoked to bar disparate impact claims under the PDA when it is the product of attitudes and practices it is the object of Title VII to proscribe.

Where an employer of a predominantly female workforce adopts "neutral" policies that exclude on the basis of pregnancy, the impact of such policies can be discerned, not in the aggregate number of women hired, but in the rate of employee turnover. The foreseeable impact of such practices illuminates their implicit sexual premise: that woman's labor force participation is, by virtue of her reproductive role, short term, occasional. Women as a class are implicated by such policies, socially and economically. ${ }^{107}$ Under the PDA, such policies should be challengeable on disparate impact grounds, as they circumscribe the "terms [and] conditions"108 of women's employment "because of or on the basis of pregnancy." 100 The absence of men in a particular job category renders the sexual norm upon which a pregnancy exclusion is predicated less apparent-not less real.

\section{Pregnancy Discrimination in Social Context}

Pregnancy discrimination exhibits a coherent social logic. The exclusion of the pregnant employee reaffirms woman's essential nature as maternal, her proper sphere as domestic. Pregnancy-based exclusions disrupt women's labor force participation, thus ensuring that they remain second class, occasional labor. The cycle is self-perpetuating: Social practice determines the meaning of a woman's biology, even as biology appears to be determining women's social fate.

Since the early nineteenth century, women's maternal role has been understood to render them unfit for employment. ${ }^{110}$ Since the turn of the

106. Public school teachers and airline flight attendants have figured most frequently as plaintiffs in pregnancy discrimination litigation. (For examples of public school regulation, see Thompson v. Board of Educ., 526 F. Supp. 1035 (W.D. Mich. 1981), rev'd, 709 F.2d 1200 (6th Cir. 1983), and of airline regulation, see supra pp. 944-45.) The predominance of young women of childbearing age in these jobs has not disposed employers to view the situation of the pregnant employee as normal, but rather to intensify its exclusionary regulation. The general animus toward pregnancy in the workplace is readily exacerbated in sex-typed occupational roles. As a comparison of the school and airline contexts suggests, the pregnant employee can violate her prescribed role by displaying either an excess, or a lack, of sexuality.

107. It has long been recognized that the occupational segregation of women enables employers to reap the benefits of their depressed earning capacity. See C. DEGLER, supra note 102, at 424-25 (wage disparity is "the most obvious cause, and consequence for women, of [a] long history of job segregation"). When a job has been defined to exclude pregnancy, women's labor force participation is disrupted, and wages further depressed. Congress recognized the interactive role of pregnancy discrimination and job segregation in exacerbating the wage gap, citing it as a compelling reason for adopting the PDA. See 123 CoNG. REC. 29,385 (1977) (statement of Sen. Williams); S. REP. No. 331, supra note 13 , at 6 .

108. 42 U.S.C. $\S 2000 \mathrm{e}-2(\mathrm{a})(1)(1982)$.

109. 42 U.S.C. $\$ 2000 \mathrm{e}(\mathrm{k})(1982)$.

110. The ideology of separate spheres (which denominates productive labor male and domestic 
century, women's employment has been subjected to pronatalist regulation, circumscribed in the name of a public interest in their reproductive capacity. ${ }^{111}$ Employers have consistently excluded the pregnant employee, when it was in their economic self-interest, and even when it was not. ${ }^{112}$ Eradicating pregnancy discrimination will require confronting and dismantling this history-not by denying women's reproductive difference, but by reforming the institutions that have constructed its social meaning.

Litigation of PDA claims to date has failed to confront the relation of reproductive difference to women's secondary socio-economic status. Adherents to a parity interpretation of the amendment recognize that pregnant women have been subjected to exclusionary treatment in the workplace, but propose to rectify this tradition by denying that pregnancy

labor female) can be traced to the early nineteenth century, when industrialization initiated the removal of production from the home. See, e.g., N. COTT, THE BONDS OF WOManhood 63-74 (1977); A. Kessler-HARRIS, supra note 105, at 45-72; J. MATTHAEI, supra note 102, at 101-19; Olsen, The Family and the Market: A Study of Ideology and Legal Reform, 96 HaRv. L. REv. 1497, 1499-1501 (1983). During the nineteenth century, the cult of domesticity defined women's role with reference to family obligations; employment of wives and mothers was asserted to conflict with the primary duty they owed to home life. In the early twentieth century, the cult of domesticity fused with eugenicist concerns. Rhetoric of familial obligation was displaced by rhetoric of biological necessity, and objections to women's employment came to focus specifically on their reproductive role. Women's employment was now asserted to threaten, not only the integrity of the family, but the vitality of the race. For a succinct illustration of this transformation, compare Bradwell v. Illinois, 83 U.S. 130, 141-42 (1872) (Bradley, J., concurring) ("The harmony [of] the family institution is repugnant to the idea of a woman adopting [an] independent career from that of her husband.") with Muller v. Oregon, 208 U.S. 412, 421 (1908) (regulation of women's employment necessary "to preserve the strength and vigor of the race"). See generally L. Gordon, WOMAN's Body, Woman's Right: A SOcial History OF BIRTH CONTROL IN AMERICA 126-58 (1976) (excellent documentation of eugenics movement); M. Fovcault, The History of Sexuality (R. Hurley trans. 1978) (especially Part IV) (theoretical account of eugenics movement within history of middle-class political culture).

111. During a period in which the Fourteenth Amendment was held to bar state regulation of the employment relationship, see Lochner v. New York, 198 U.S. 45 (1905), regulation of women's employment was upheld by the Supreme Court in Muller v. Oregon, 208 U.S. 412, 421-22 (1908), on the following grounds:

That woman's physical structure and the performance of maternal functions place her at a disadvantage in the struggle for subsistence is obvious. This is especially true when the burdens of motherhood are upon her. Even when they are not, by abundant testimony of the medical fraternity continuance for a long time on her feet at work, repeating this from day to day, tends to injurious effects upon the body, and as healthy mothers are essential to vigorous offspring, the physical well-being of woman becomes an object of public interest and care in order to preserve the strength and vigor of the race.

For a doctrinal history of protectionist legislation, see J. Baer, The Chains of Protection: The Judicial Response to WOMEn's LABOR Legislation (1978). For an excellent historical overview of protectionist regulation of women's employment, see A. KESSLER-HARRIS, supra note 105, at 180-214. Regulation specified maximum hours and minimum wages, prohibited night work, and imposed blanket exclusions of women from particular occupations. See generally WOMEN's BuREAU, U.S. Dep't of Labor, Bull. No. 66-II, Chronological Development of Labor Legislation IN THE UNITED STATES (1932) (catalogue of legislation by state).

112. Pregnancy-based discharges and mandatory maternity leaves operate to deprive employers of skilled employees. In the public school context, for example, such policies have traditionally operated to disrupt the service of teachers during the academic year. See Cleveland Bd. of Educ. v. LaFleur, 414 U.S. 632, 640-43 (1974); see also Nashville Gas Co. v. Satty, 434 U.S. 136, 143 n.5 (1977) (policy of denying seniority to employees returning from maternity leave favors inexperienced over experienced employees, and affects morale of female employees generally). 
poses any relevant legal differences whatsoever. By refusing, in the name of equality, to acknowledge the biological and social specificity of women's reproductive role, the parity standard naturalizes an entire history of antipathy to the pregnant employee: Pregnancy is a disability like any other. ${ }^{113}$

Social relations are hierarchically organized around the reproductive difference that exists between women and men. ${ }^{114}$ Reproductive difference is socially selected to define gender, and in this process, given social value by institutions and ideologies of inequality. As a growing number of feminist scholars now argue, a doctrine of sexual equality must recognize reproductive difference in order to scrutinize inegalitarian relations predicated upon it in the political and economic spheres. ${ }^{115}$ The fact of

113. Wendy Williams has provided the most sustained defense of the parity standard to date. See Williams, supra note 15 . She strenuously opposes legal recognition of reproductive difference on doctrinal and historical grounds. For Williams, there is no distinction between doctrinal recognition of pregnancy-specific rights and doctrinal ratification of practices that penalize women on the basis of pregnancy. "If we can't have it both ways, we need to think carefully about which way we want to have it." Id. at 196. Williams views the claim to job security for pregnant women as perpetuating the legacy of protectionist legislation.

Williams' doctrinal analysis is constrained by an excessive formalism. A distinction can and should be drawn between laws and practices that assume pregnancy to be antithetical to employment, and those that presume their compatibility. See Brief for Amicus Curiae Equal Rights Advocates at 35-38, California Fed. Sav. \& Loan Ass'n v. Guerra, Nos. 84-5843 and 84-5844 (9th Cir. 1984); Krieger \& Cooney, supra note 15 , at 531-33.

Williams raises a more compelling concern when she argues that recognizing pregnancy-specific rights may perpetuate the legacy of protectionist legislation. As a key proponent of the PDA, she does not, however, advocate that the state refrain from regulating in the field. Rather, she apparently believes that the state can, and should, intervene to protect women in sex-neutral terms; and that such an intervention is both necessary and sufficient to alter attitudes toward pregnancy in the workplace. But the parity standard Williams would have the state enforce is not sex-neutral. The state cannot regulate a sex-specific condition in sex-neutral terms; a judgment about women is necessarily involved. It can, however, attempt to neutralize the sex-specific effects of its former regulatory policies by ensuring that pregnancy is treated as a normal condition of employment. Such an intervention is preferable to Williams' proposal that the state once again regulate women's employment in terms that characterize pregnancy as a disability, however normal. Furthermore, characterizing pregnancy as a normal disability will not, as Williams suggests, alleviate hostility toward pregnancy in the workplace. Because the parity standard does not eliminate real conflicts between pregnancy and employment, it will not eradicate the deep-seated belief that women's reproductive role unfits them for employment. Indeed, it gives it new legitimacy. When the state claims to remedy a history of employment discrimination against pregnant women, eliminating only overt expressions of that tradition and leaving its deeper institutional legacy intact, it legitimates, as natural, inequalities having a determinate social history. According women "equality" on such terms dispossesses them of an equality claim commensurate with this history.

114. Mary O'Brien gives far-ranging explication to this thesis in M. O'Brien, The Polrtics of REPRODUCTION (1981). Her analysis is flawed, however, by its incomplete repudiation of biological explanations for the social relations she so acutely describes. For similar analysis advanced in consistently social terms, see Z. Eisenstein, Feminism and Sexual Equality: Crisis in Liberal AMERICA 234-37 (1984).

115. A variety of feminists have advanced theories of equality premised on recognition and affirmation of sexual difference. Their work is critically reviewed by Zillah Eisenstein, supra note 114, at 161-254, who refuses to relinquish a vision of heterogeneous human possibilities. Eisenstein argues, however, that such a transformation in gender relations can be achieved only by dismantling the ideologies and institutions subordinating women on the basis of their reproductive role. A theory of sexual equality must recognize this biological difference between the sexes in order to depoliticize it. 
reproductive difference should neither foreclose equality analysis, ${ }^{116}$ nor deflect it into a search for comparable cross-sex characteristics. ${ }^{117}$ Rather, direct inquiry is warranted: Do laws, policies, and practices that exert a differential impact on the sexes by virtue of reproductive difference serve to perpetuate women's secondary socio-economic status, or to maintain sex roles integral to that status? ${ }^{118}$ This inquiry into the social valuation of sexual difference lacks the obvious coherence of the more traditional, formalist inquiry: Has similar treatment been accorded the similarly situated? But given that "the sexes are neither the same nor, in a sexist society, similarly situated,"119 this inquiry possesses a practical power formalist analysis necessarily lacks. ${ }^{120}$ Doctrine must explore the social logic of sex discrimination if it is to eradicate more than its formal manifestations. ${ }^{121}$

Id. at 206-07. For similar developments in feminist legal scholarship, see Law, supra note 10; see also Krieger \& Cooney, supra note 15; Scales, supra note 15.

116. This is in essence the holding of the Gilbert opinion and of Geduldig v. Aiello, 417 U.S. 484 (1974), the constitutional precedent whose reasoning Gilbert adopted.

117. This is in essence the model of the parity standard, which insists, without exception, that treatment of pregnancy be evaluated with reference to other (non-reproductive) disabilities. For a discussion of the "problem of the strained analogy" endemic to scrutinizing sex differences in terms of comparable cross-sex characteristics, see Krieger \& Cooney, supra note 15, at 539-44.

118. For purposes of constitutional analysis, Sylvia Law has proposed that:

laws governing reproductive biology should be scrutinized by courts to ensure that (1) the law has no significant impact in perpetuating either the oppression of women or culturally imposed sex-role constraints on individual freedom or (2) if the law has this impact, it is justified as the best means of serving a compelling state purpose.

Law, supra note 10, at 1008-09. Law would limit this inquiry to laws governing reproductive biology. Her formulation of the test, however, derives from a more far-reaching inquiry proposed by Catharine MacKinnon, who would recast sex discrimination analysis in the following terms:

The only question for litigation is whether the policy or practice in question integrally contributes to the maintenance of an underclass or a deprived position because of gender status. The disadvantage which constitutes the injury of discrimination is not the failure to be treated "without regard to" one's sex. . . . The unfairness lies in being deprived because of being a woman or a man, a deprivation given meaning in the social context of the dominance or preference of one sex over the other....

Under the inequality approach, variables as to which women and men are not comparable, such as pregnancy or sexuality, would be among the first to trigger suspicion and scrutiny, rather than the last ....

C. MACKINNON, supra note 8, at 117-18.

119. C. MacKinnon, supra note 8 , at 119 .

120. The creed of similar treatment for the similarly situated expresses the normative vision that the sexes ought stand as political and economic equals. The transformative power of this vision is considerably diminished when it is transposed into an analytical method for evaluating equality claims. Where the normative principle of equality among the "similarly situated" is taken as a description of those raising equality claims deserving of legal recognition, analysis will tend to ratify existing inequalities, rather than eradicate them. See C. MACKInNon, supra note 8, at 101-41.

121. Race discrimination has a publicly adjudicated history, one which repudiates biological explanations of racial status, acknowledging the role of attitudes and institutions in perpetuating racial hierarchy. By contrast, the law of sex discrimination has yet to develop such a history. Its reliance on the simple notion of "stereotypes" does not do justice to the complex ideological and institutional basis of sexual hierarchy, a system that relies on differences-real and imagined, made and found-to legitimate itself. Within the system, all differences invoked to justify women's socio-economic status 


\section{CONCLUSION}

Sexual equality does not concern the innate similarity, but the relative social status of the sexes. Women may raise a pregnancy-specific equality claim because society has consistently selected that "difference" as a basis for their economic subordination. Where tradition has presumed the incompatibility of pregnancy and employment, the PDA now substitutes a countervailing presumption of compatibility. Its mandate, fully consistent with Title VII's larger remedial objectives, must be given full force. Recognizing a disparate impact claim of pregnancy discrimination would require simply that pregnancy be treated as a normal condition of employment, barring institutional as well as individual presumptions to the contrary. At root, recognizing such a claim accords women the dignity of a history-acknowledging that the primary determinants of their economic status are social, not biological, in origin.

-Reva B. Siegel

are functional equivalents, whether stereotypically, statistically, or absolutely true. They serve to justify women's status where a social allocation of power is so deeply embedded as to appear part of the natural order of things. An antidiscrimination doctrine that defines equality as a matter of similarity and equivalence, without inquiring into the genesis and logic of "differences" among the socially unequal, will create a law of equality hopelessly unequal to its stated object. The danger is that such a law will itself naturalize the inequities it purports, comprehensively, to proscribe. 